\title{
Portuguese Origins of a 16th Century Aqueduct in México ${ }^{1}$
}

\author{
Portuguese Origins of a $16^{\text {th }}$ Century Aqueduct in México
}

\section{El origen portugués de un acueducto del siglo XVI en México}

\author{
William E. Doolittle ${ }^{2}$ \\ The University of Texas at Austin, USA
}

\begin{abstract}
Many aqueducts built during the Spanish colonial era remain standing in México, albeit not functioning. A few date to the $16^{\text {th }}$ century. Some of these early aqueducts are quite spectacular and highly visible. Others are small and are located in places not easily found. Despite their size, small aqueducts are important for understanding knowledge pertaining to technology transfers from the Old World to the New. One such aqueduct is on the property of the Hacienda de Pacho, near Xalapa in the state of Veracruz. One of its highly unusual characteristics is that its construction involved Gothic arches. No other colonial aqueduct in México has such features. According to documentary courses dating to AD 1591, it was built by the hacienda's original owner who was from the Portuguese island of Madeira. This paper reports on field activities involved in verifying the Maderian origins of this unique aqueduct.
\end{abstract}

Keywords: Mexico, Madeira, landscapes, aqueducts, technology transfers

1 This paper is part of the Bridging Troubled Waters Project, a long-term study of the transfer and hybridization of technological knowledge pertaining to the construction of aqueduc bridges, Renaissance Spain to Viceregal México. Except as noted in figure captions, all photographs were taken by the author. I thank Marisa Moolick Gutíerrez and William Cruse, current owners of the Hacienda de Pacho, for their hospitality and insights, and Matt Fry and Matt La Fevor for their assistance inspecting aqueducts in México.

2 William E. Doolittle is the Erich W. Zimmermann Regents Professor of Geography, The University of Texas at Austin. USA. Gmail: dolitl@austin.utexas.edu, Department of Geography and the Environment, 305 East 23rd Street, Austin, Texas 78712, USA.

Este artículo corresponde a la ponencia presentada en el 35th Conference of Latin American Geographers realizada en San José, Costa Rica del 20 al 22 de mayo del 2018. 


\begin{abstract}
Resumen
Muchos acueductos construidos durante la época colonial española permanecen en México, aunque no funciona. Algunos datan del siglo XVI. Algunos de estos primeros acueductos son bastante espectacular y altamente visible. Otros son pequeños y se encuentran lugares que no se encuentran fácilmente. A pesar de su tamaño, los acueductos pequeños son importantes para comprender el conocimiento relacionado contransferencias de tecnología del Viejo Mundo al Nuevo. Uno de estos acueductos está en la propiedad de Hacienda de Pacho, cerca de Xalapa en el estado de Veracruz. Uno de sus muy inusual características es que su construcción involucró arcos góticos. Ningún otro acueducto colonial en México tiene tales características. De acuerdo con los cursos documentales que datan del año 1591, fue construido por el dueño original de la hacienda que era de la isla portuguesa de Madeira. Este papel informes sobre las actividades de campo involucradas en la verificación de los orígenes de Maderian de este acueducto único.
\end{abstract}

Palabras clave: México, Madeira, paisajes, acueductos, transferencia de tecnología

Much of México's cultural landscape is the product of Spanish colonial influences. This is perhaps no better reflected than in the architecture of churches, monasteries, government buildings, haciendas, and infrastructure constructions such as bridges, dams, and aqueducts. The later are particularly important geographical features as they are not only artificial hydraulic systems that required environmental understanding and engineering skills to build, but the arcades often associated with them, reflect different building materials, construction techniques, and human creativity. Piers, spandrels, voissoir, and other components vary considerably from one aqueduct to another. One characteristic that varies little is the arch, most are round. Scores of aqueducts built in México during the $1500 \mathrm{~s}, 1600 \mathrm{~s}$, and $1700 \mathrm{~s}$ reflect this design. One, however, does not. It dates quite early in the colonial era and its construction is attributed to someone not from Spain. This paper discusses that aqueduct, its origins, technology transfers, and in the process raises questions about landscape transformations. It also demonstrates, using a number of photographs, why geographical field work is essential in corroborating historical arguments based on documentary evidence.

\title{
Hacienda de Pacho
}

Some aqueducts were built in order to bring water into cities, as was the case in Morelia, Michoacán, or to missions, as was the case at Otumba, in what is now the state of Hidalgo. Such aqueducts are very large and visually striking (Figure 1). In contrast, a number of aqueducts are quite 
small and were built by private land owners for economic purposes. One such aqueduct was constructed on the grounds of the Hacienda de Pacho, six kilometers southeast of Xalapa, Veracruz.

Figure 1. The aqueduct at Otumba, Hidalgo, México built in the 1540s, purportedly under the direction of Fray Francisco de Tembleque (Valdes 1961)

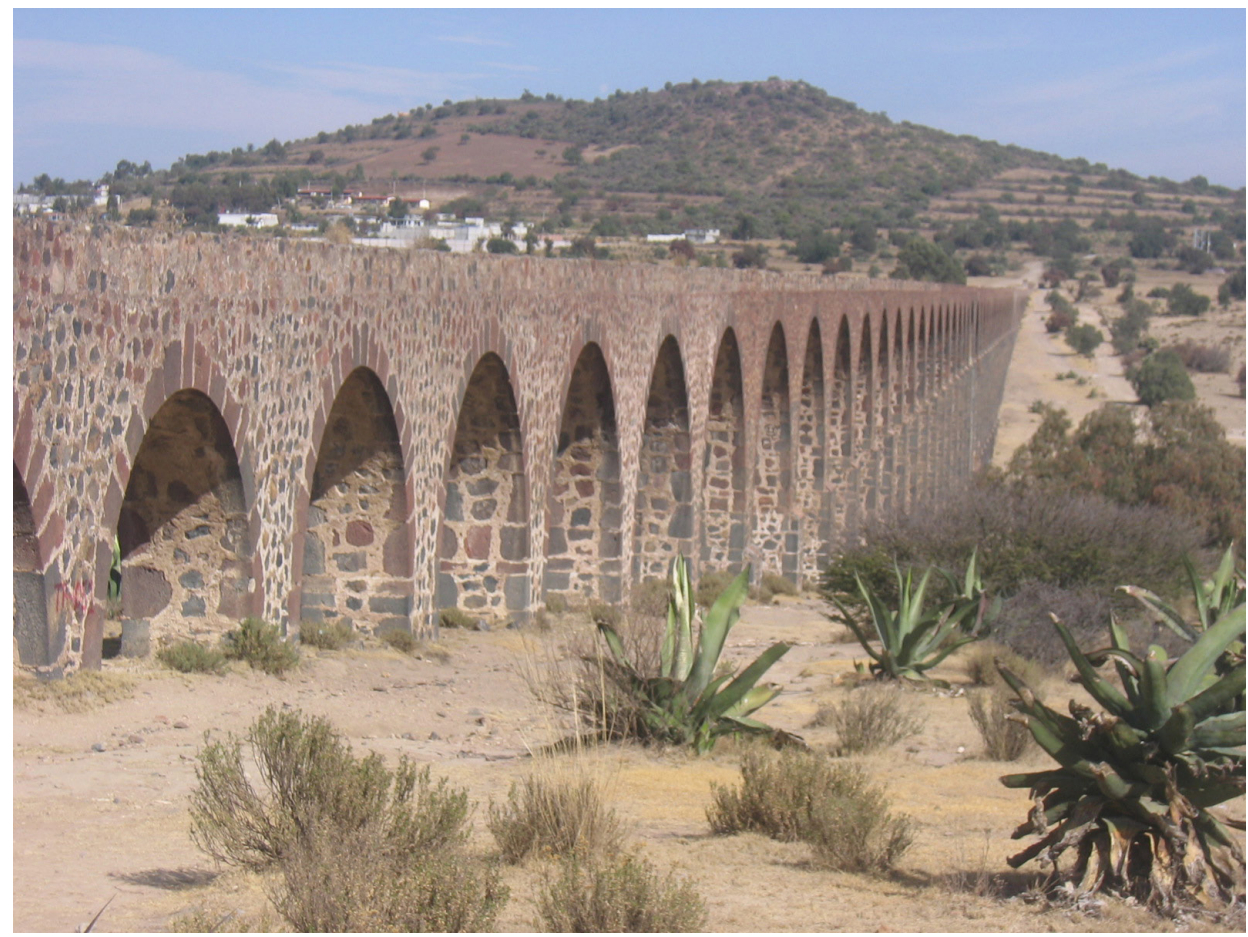

The principal building of this hacienda is quite beautiful (Figure 2), so stunning "' in fact that it appeared in the motion picture Collateral Damage, featuring Arnold Schwartznegger, and on a book cover (Cambrezy \& Lascuráin 1992). Other buildings on this hacienda are not so aesthetically remarkable. One of these is a mill (Figure 3 ) that was powered by water emanating from a spring high up on a hill behind the hacienda compound. 
Figure 2. The front of the house at Hacienda de Pacho, Veracruz, México

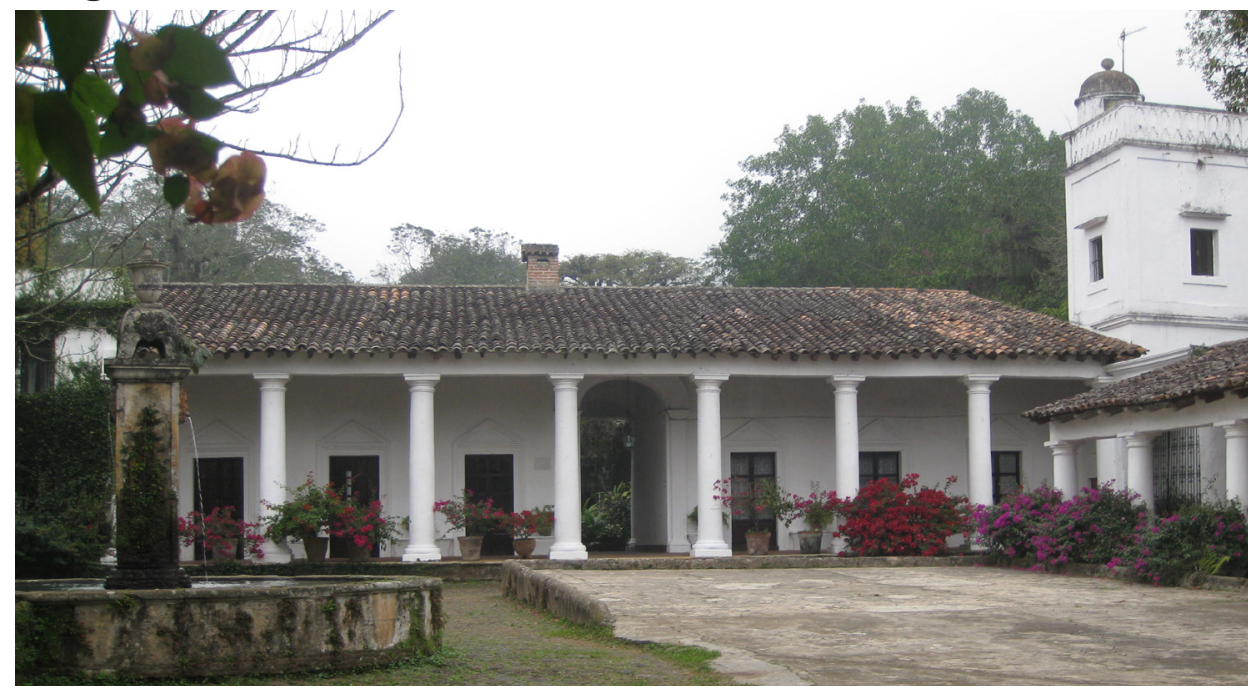

Figure 3. Profile view of the mill structure at Hacienda de Pacho. Water entered the mill through a channel in the upper right, dropped into a penstock behind the arch on the right, and turned a milling device below. Water exited the mill via a chase behind the lowest arch visible in the lower left.

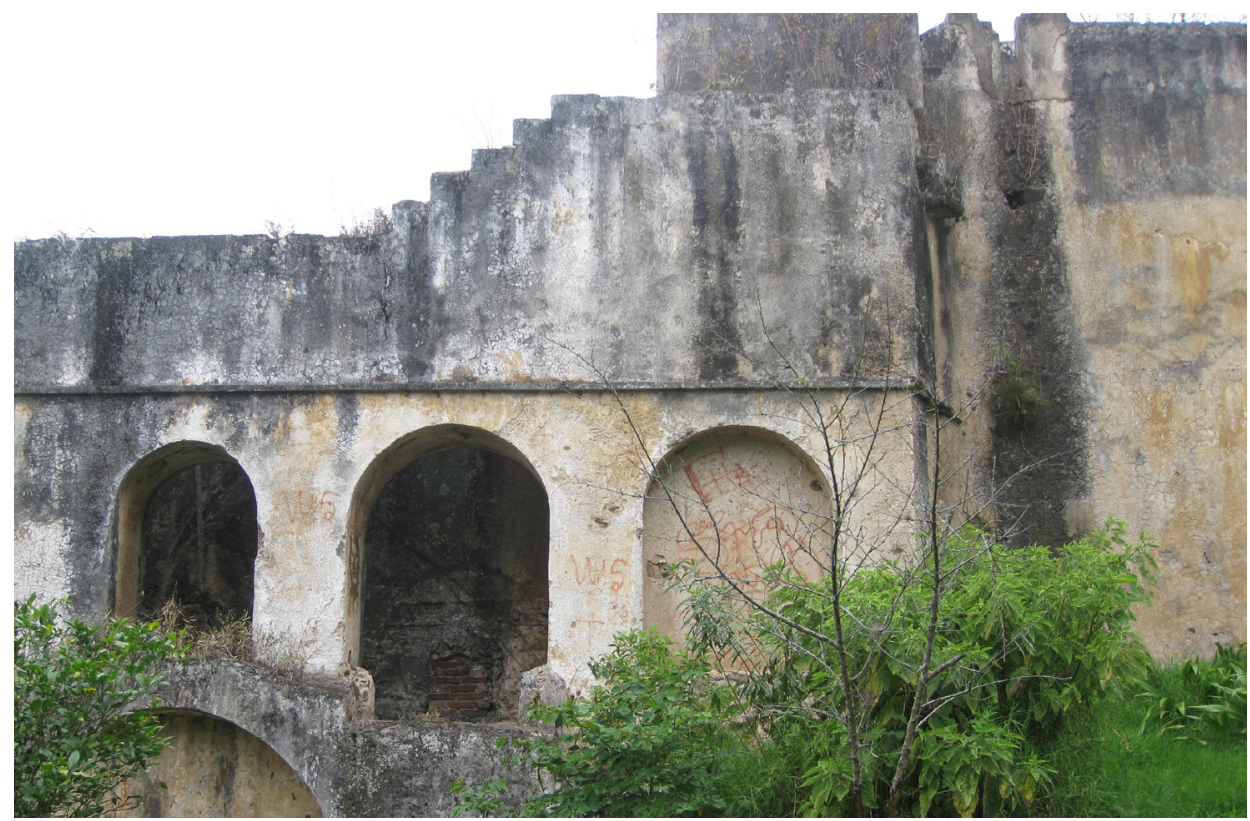


According to research conducted by Lic. Iván Hillman Chapoy (2007), Hacienda de Pacho was registered in the Archivo Notarial de Xalapa as the Ingenio de Nuestra Señora de los Remedios de Nexapa in AD 1592. As the name implies, it was a sugar mill. The hacienda was established by Juan de Quiroz, who hailed neither from mainland Spain nor the Canary Islands, as might be expected, but from the Portugeuse island of Madeira.

\section{The Aqueduct}

Conveying water from the spring on the hill to the mill below involved the construction of an aqueduct bridge (Figures 4 and 5). Two aspects of this feature are strikingly apparent, its unusual arches and signs of renovation. To the best of my knowledge, and I have examined scores of aqueducts, this is the only one with Gothic arches in all of México (Figure 6).

Figure 4. View along the top of the aqueduct that carried water from the spring to the mill

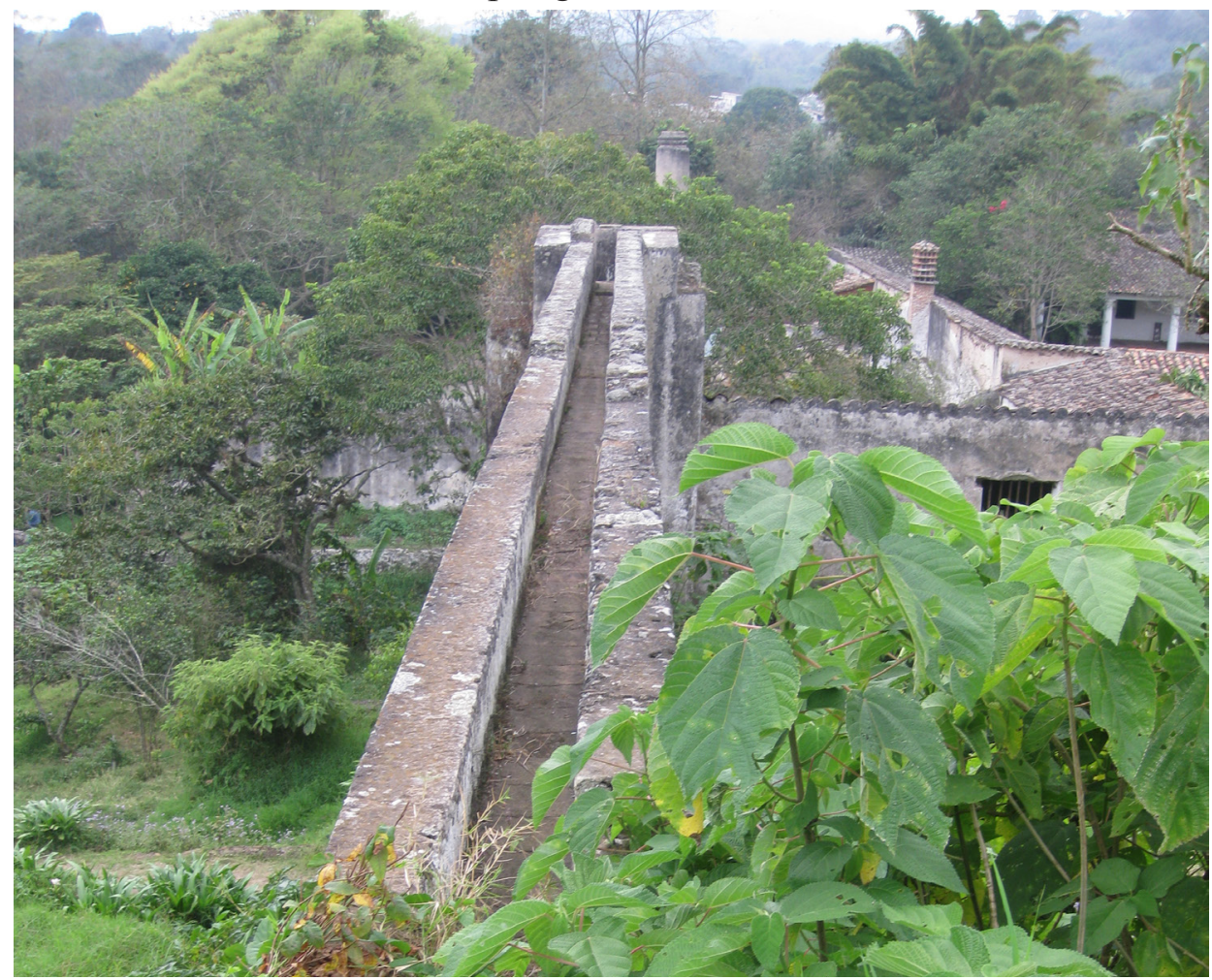


Figure 5. The aqueduct at Hacienda de Pacho. Note the mill structure and penstock on the left.

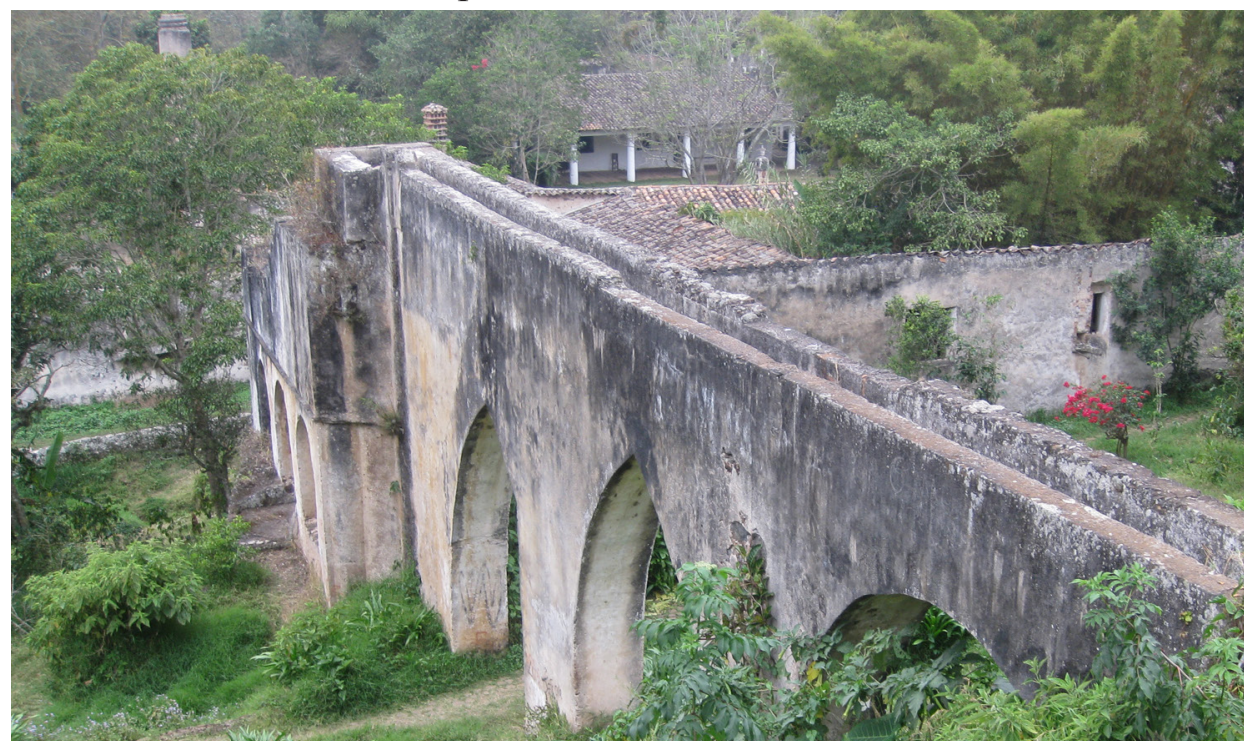

Figure 6. In addition to having a circular arch (right) this aqueduct is characterized by Gothic arches.

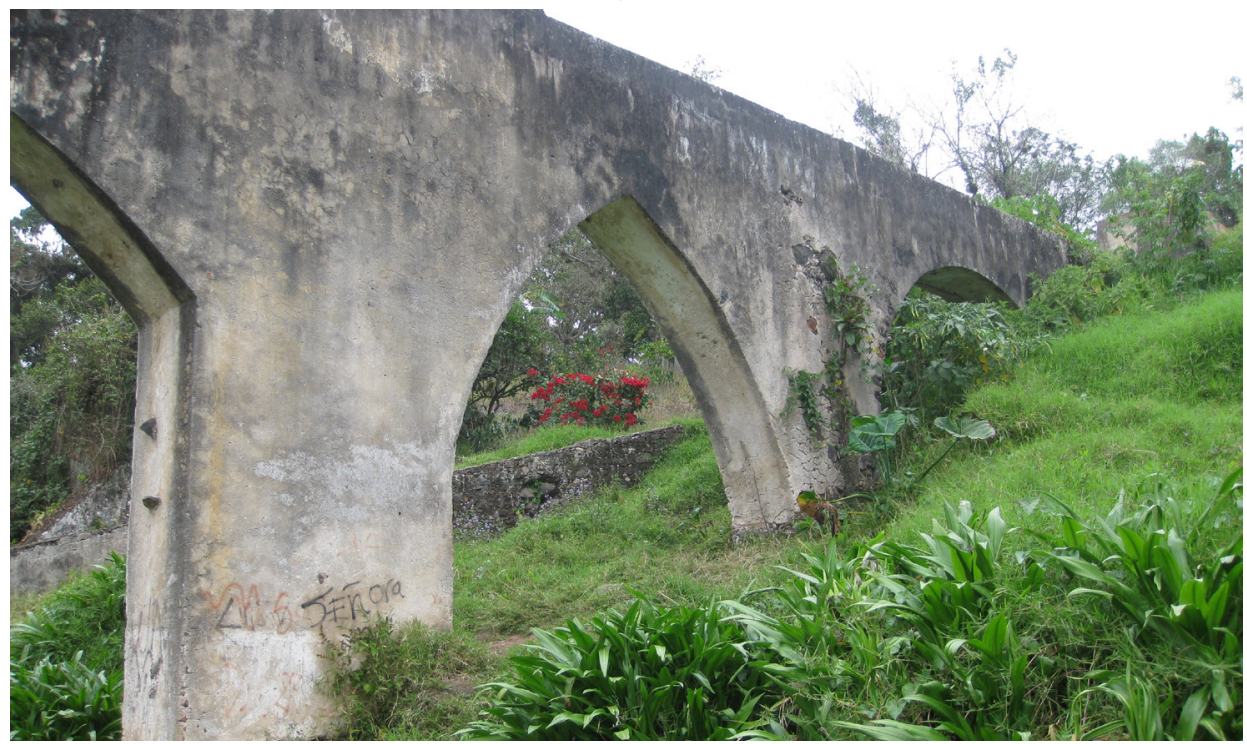

472 Revista Geográfica de América Central No 61E (3) Especial CLAG Este artículo está bajo una licencia

$\begin{array}{ll}\text { e-ISSN 2215-2563 • Julio-diciembre 2018 •pp. 467-488 } & \begin{array}{l}\text { Atribución/Reconocimiento-NoComercial- } \\ \text { Compartirlgual 4.0 Internacional }\end{array}\end{array}$ Doi: http://dx.doi.org/10.15359/rgac.61-3.24 
Many aqueduct bridges in México and elsewhere show signs of renovation, and this one is no exception (Figure 7). The pier between the two Gothic arches appears to have been enlarged, for reasons unknown. This is most apparent when the arches themselves are compared. One is a perfect Gothic arch with the curve of the soffit being tangent to the pier. In contrast, the curvature of one side of the other arch is not tangent to the pier. This suggests that the pier used to be narrower than it is now, and was widened, thereby narrowing the span of one arch.

Figure 7. A view opposite that of Figure 6. Clearly evident are the widened pier/narrowed span, and the addition of a penstock.

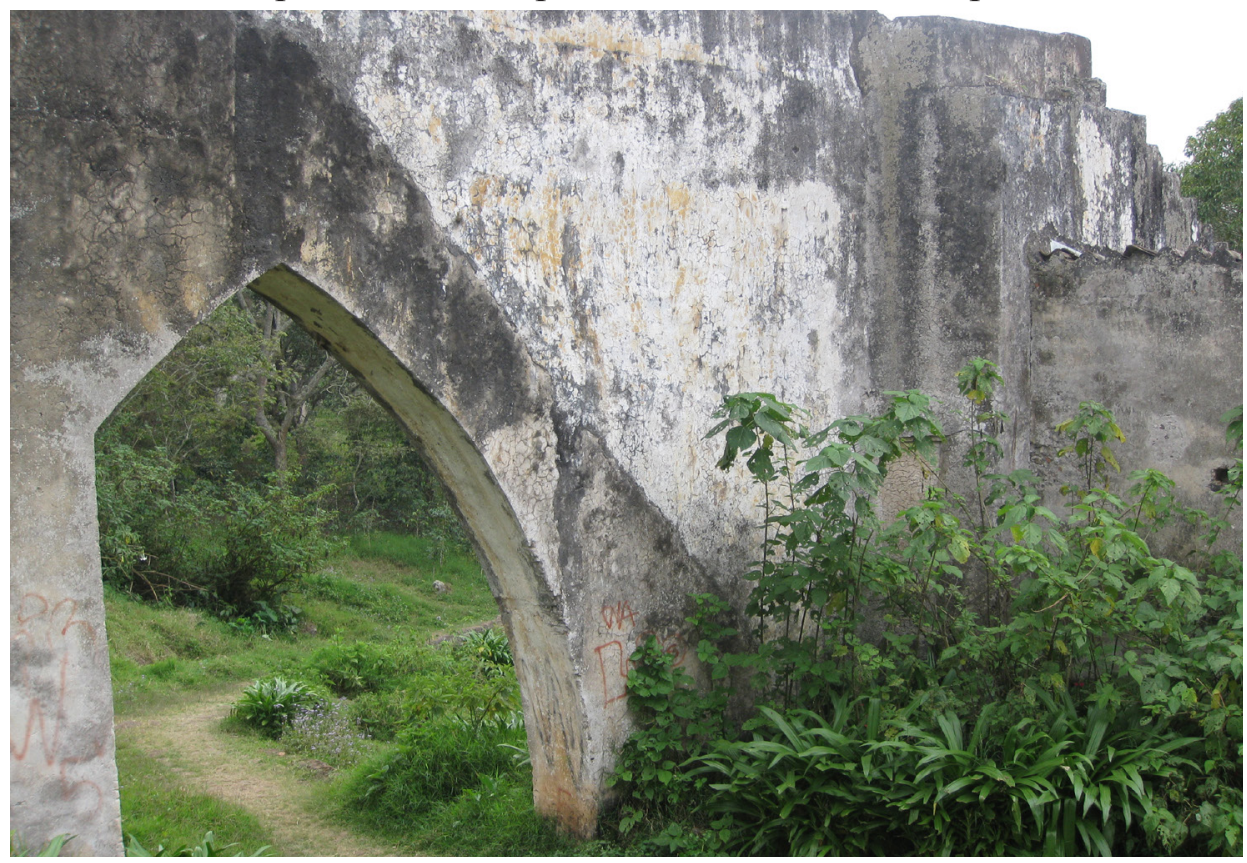

Another renovation is evident by a conspicuous difference in plaster. Note the sharp line running from the upper left to the lower center in Figure 7. The white plastered area to the upper right of this line is a clear indication that the mill was raised and a penstock added sometime after initial construction, perhaps in the $19^{\text {th }}$ century. Hacienda de Pacho was purchased in 1843 by José Julián Gutiérrez y Fernández who is documented as having installed new milling technology (Cambrezy \& Lascuráin 1992:125, Hillman Chapoy 2007). 
The original structure probably involved water flowing in a channel over the three arches - one circular and two Gothic - before running down a flume to the mill below. In all likelihood, the force created by the falling water turned horizontal turbines, typical of mills of the same age throughout México and Iberia, Spain, Portugal, and their Mediterranean and Atlantic islands. Water then would have exited the mill through a chase and into a canal that facilitated irrigation of fields downslope (Figure 8). The arch in the lower left corner of Figure 3 might be remains of the original mill structure. The three arches above it, the penstock, and the walled portion of the aqueduct might be the additions of Gutiérrez y Fernández.

Figure 8. The mill chase at Hacienda de Pacho through which the turbines could be accessed. Water flowed out of the mill through the covered canal in the lower right.

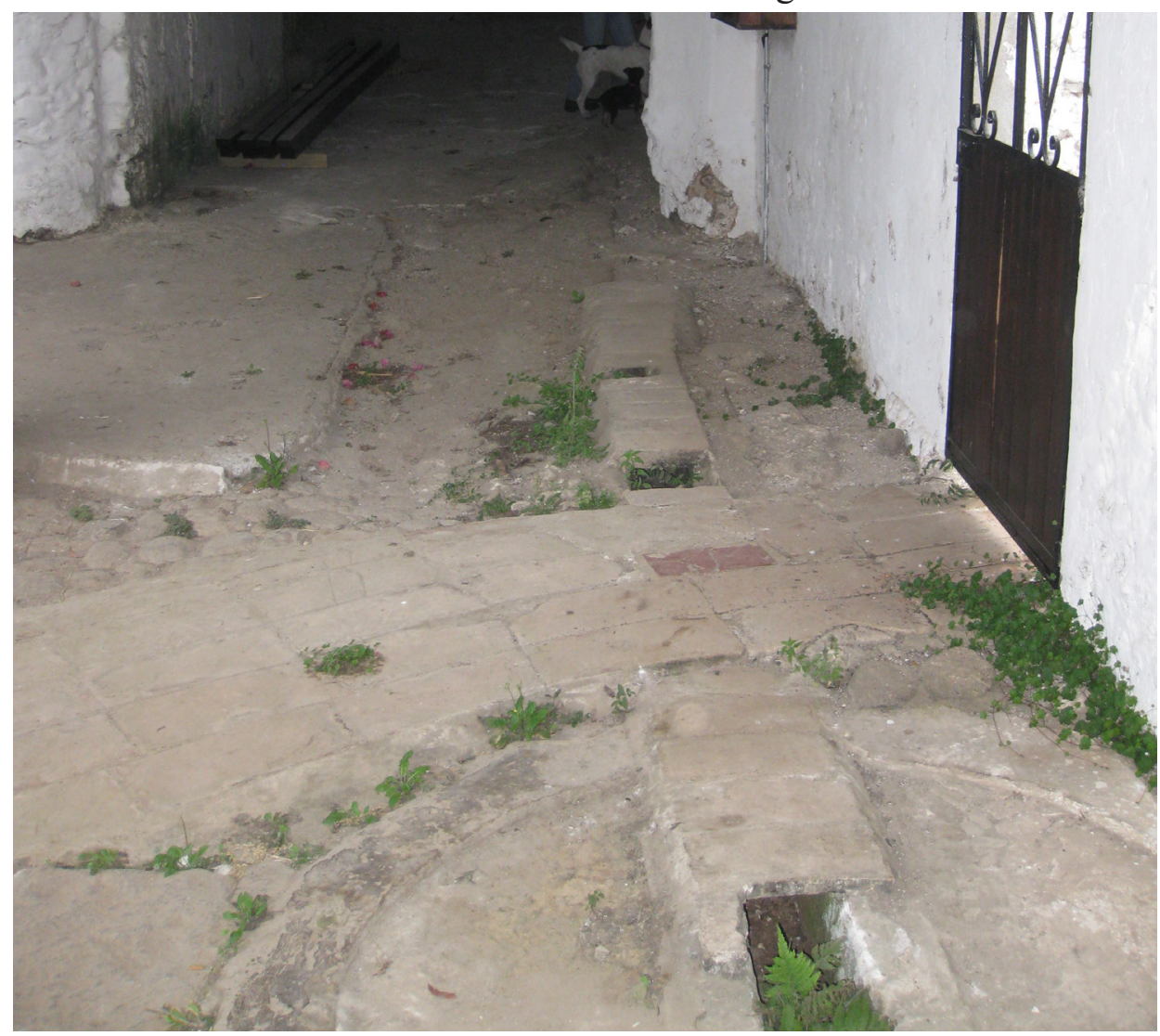




\section{Portuguese Origins}

In addition to the Gothic arches and the renovations, another interesting aspect of this aqueduct is the homeland of the original builder, Madeira, Portugal. Aqueduct bridges are common features on the landscape of Portugal, with the Águas Livres being a major landmark in Lisbon (Figure 9). Although its arches are reminiscent of the earlier Gothic style ( $12^{\text {th }}$ to $16^{\text {th }}$ centuries), the central part of this aqueduct was conceived and built between 1736 and 1744, during a time when the Baroque style (early $17^{\text {th }}$ to late $18^{\text {th }}$ centuries) flourished (Chelmicki 2008:44). Given that it was built more than a century after Hacienda de Pacho was established, The Águas Livres aqueduct could not have served as a model for its much smaller Veracruzan counterpart.

Figure 9. The Águas Livres aqueduct bridge in Lisbon with it unusual Gothic arches.

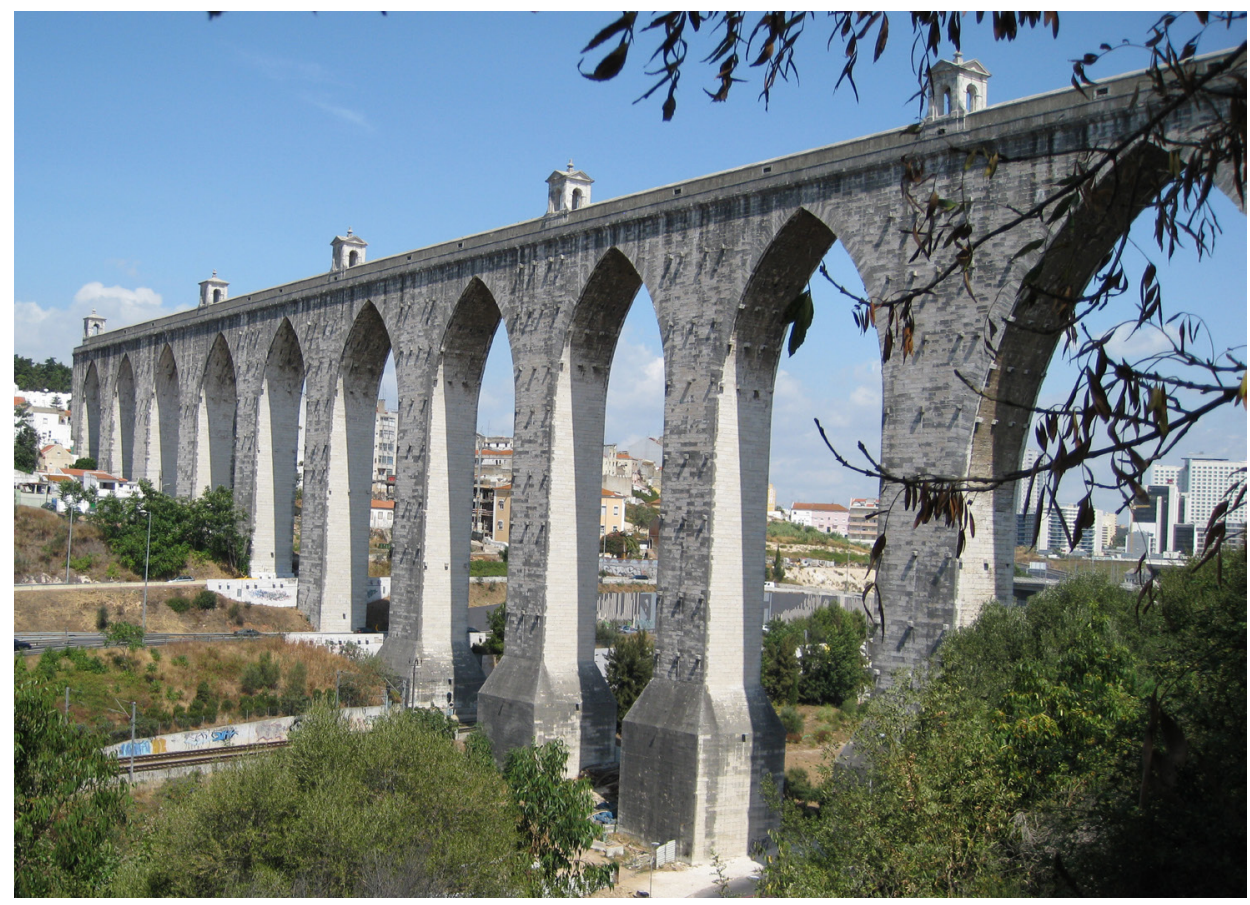

Gothic arches were commonly used in earlier constructions on Madeira, including such notable structures as the Convento de Santa Clara, completed in AD 1497, the Catedral de Nossa Senhora da Assunção 
(Figure 10), completed in AD 1514. These were two of the most important buildings in the capital, and port city of Funchal at the time. Accordingly, from wherever on Madeira the founder of Hacienda de Pacho came (Hillman Chapoy 2007), he doubtless encountered these building and hence saw Gothic arches. He was definitely familiar with technologies employed to capture, divert, and use flowing water.

Figure 10. The interior of the cathedral in Funchal, Madeira, with Gothic arches dating to AD 1514.

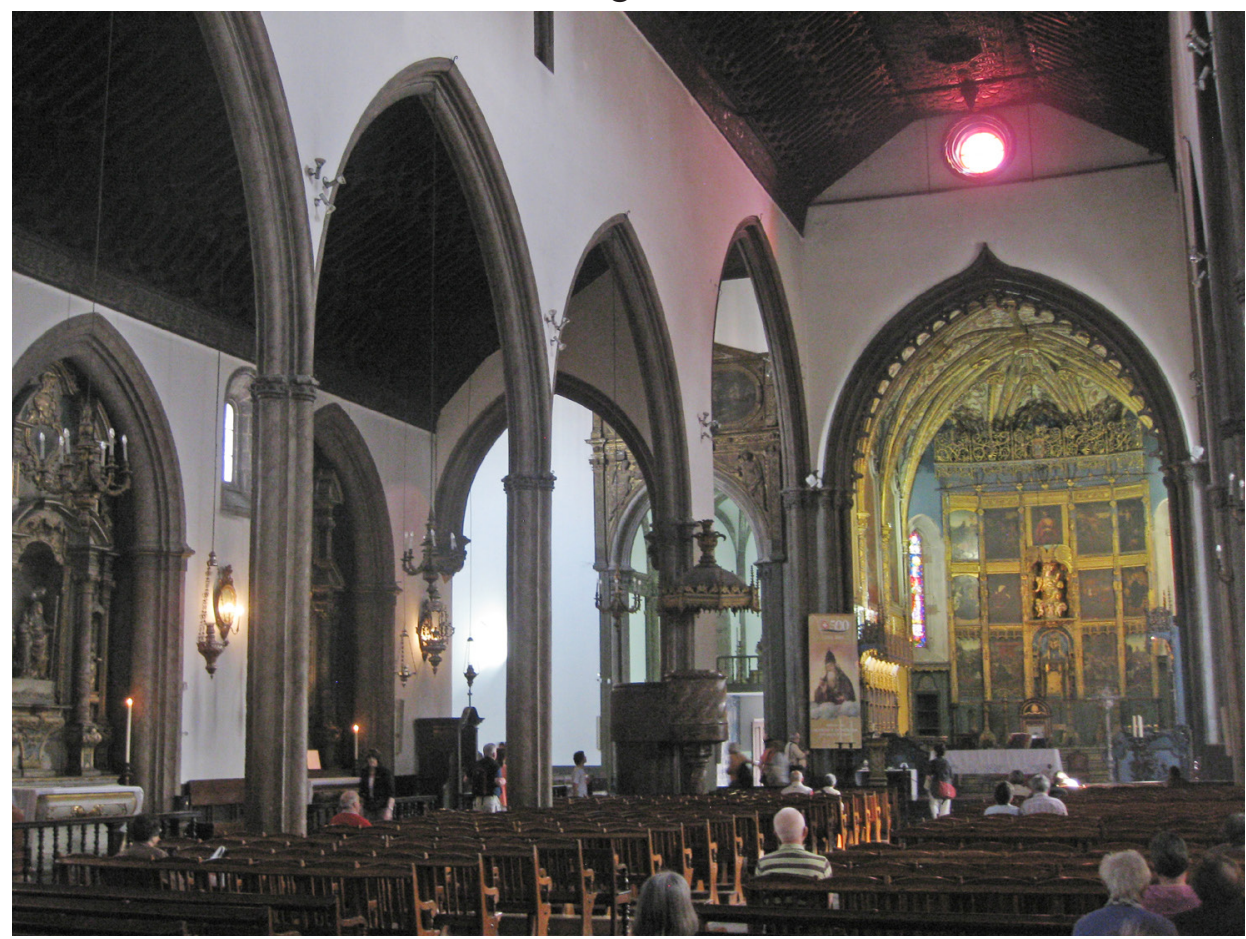

The island of Madeira is located in the Atlantic Ocean, 1000 kilometers west of the European continent. Oriented east to west, it is 57 kilometers long, 22 kilometers wide, with 150 kilometers of coast line, and maximum elevation of 1862 meters (Figure 11). As the tip of a shield volcano, the land is steeply sloping, rugged, and, as its name implies, was once heavily forested. 
Figure 11. A detailed true color satellite image of Madeira. Note the large number of gorges cut by streams running from the central highlands

toward the coast in all directions. The light green color in the lower elevations close to the coast are terraced and irrigated agricultural lands.

The reddish color areas are towns. This image was taken from NASA World Wind, onEarth WMS, and is in the public domain.

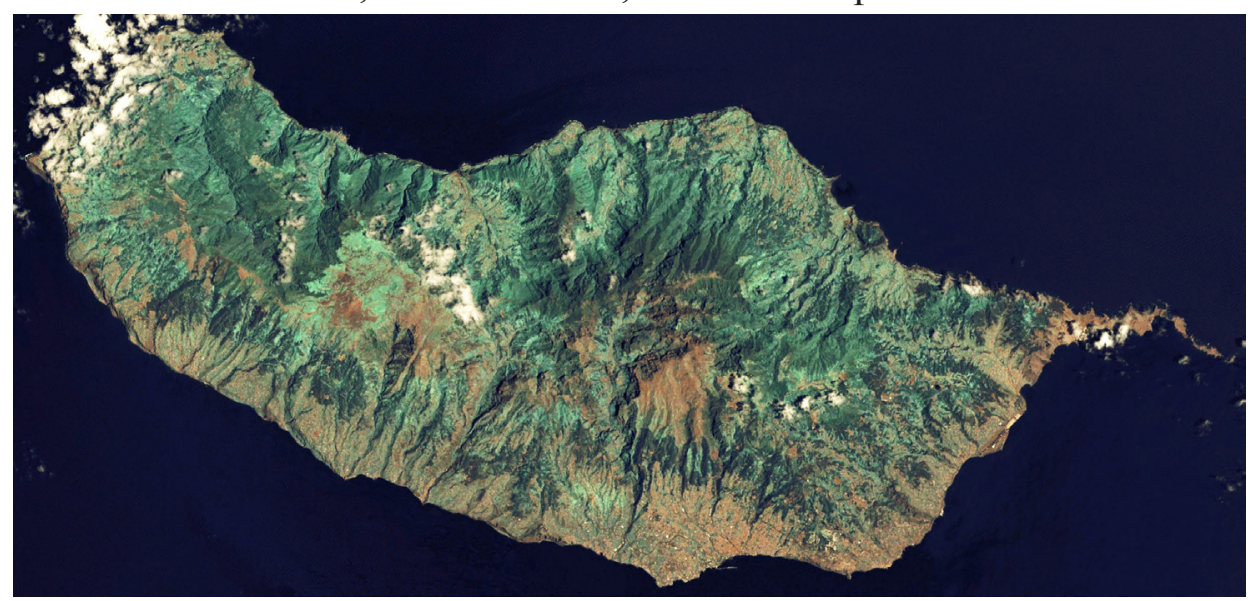

Madeira was discovered by Portuguese sailors in AD 1419. By the 1430 s trees were being harvested for ship building and construction on the mainland. Cleared areas were first used for the cultivation of wheat, but during the 1460s and 1470s agriculture shifted to sugar cane (Patel \& Moore 2017:14-16). This change had four major impacts; human, agricultural, environmental, and technological. First, enslaved people were imported from Africa as agricultural laborers. Second, along with these people came the introduction African grains rice, millet, and sorghum (Patel \& Moore 2017:33). Third, the production of molasses and alcohol required fuel that resulted in deforestation. Five-hundred hectares of forest were cleared each year and by the 1530s there were few trees left on the island. Fourth, the shape of the land and flow of water were transformed by terracing and irrigation (Patel \& Moore 2017:16-17).

With limited flat land on the island, farmers terraced the side slopes of the numerous gorges cut by streams that flow at varying rates throughout the year. To accommodate the needs of crops and humans, Madeirans constructed canals to carry water from higher elevations, where rainfall 
averages 1250 millimeters annually, to lower elevations where annual rainfall averages only 625 millimeters. Known locally as levadas, more than 2,000 kilometers of these canals remain today, with most taking on an additional life as hiking trails for tourists (e.g., Underwood 2005).

One such canal is the Levada do Moinho (Figure 12). In addition to providing water to terraces on the eastern flank of the gorge cut by the Rio Ponto do Sol, to the town of Lombada, and fields south of the town, it also powers a mill at the terminus of an aqueduct.

Figure 12. An upstream view of the Levada do Moinho and the gorge of the Rio Ponto do Sol. Note the deforested areas in the higher elevations and the terraces on the slope below the canal.

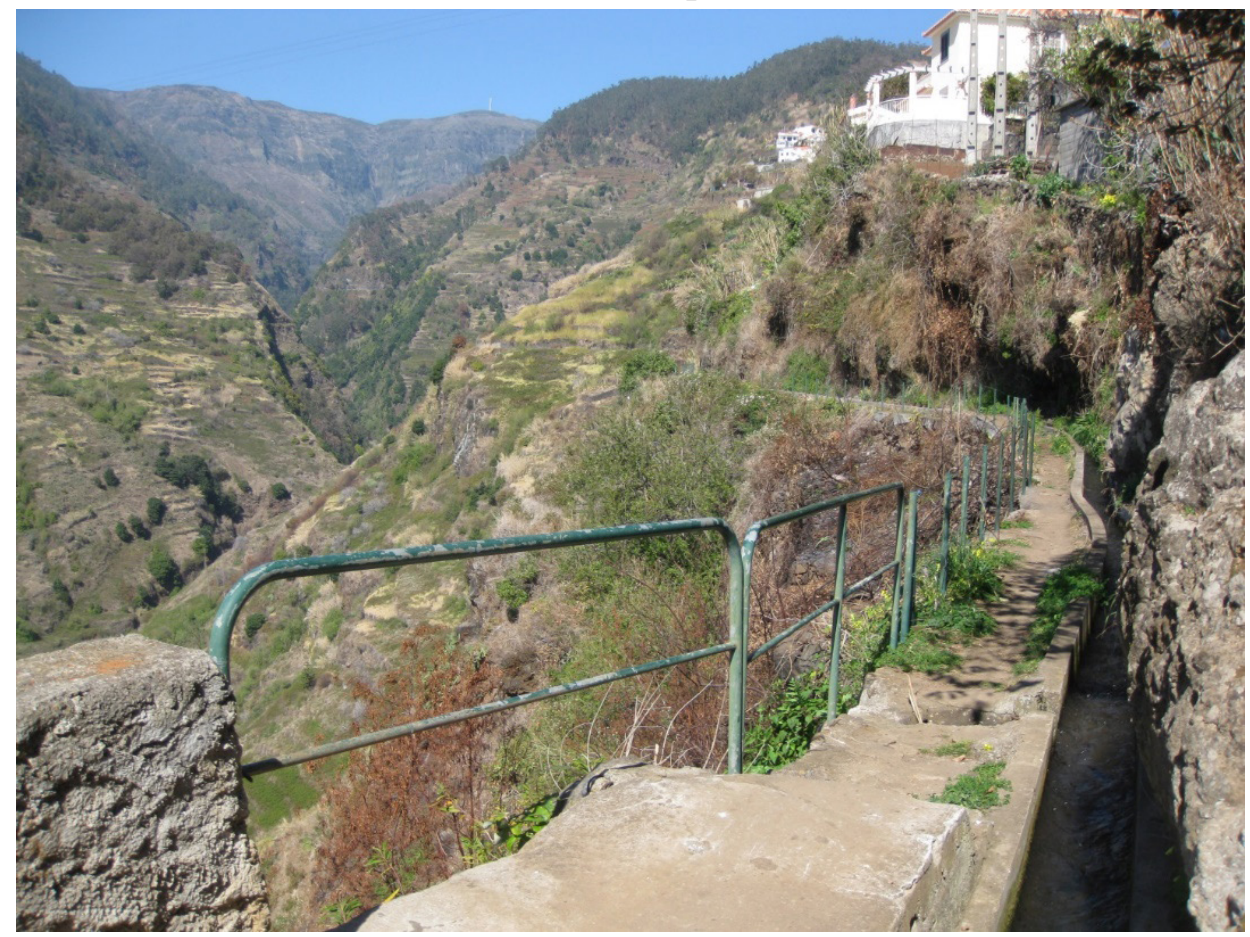

A Madeiran Aqueduct

The Levada do Moinho enters Lombada behind the northwest corner of the church that faces the town's praça (Figure 13). It flows along the west side of the church before crossing the west side of the praça on a 
small bridge aqueduct (Figure 14). Water flowing over this aqueduct empties into a penstock, from which it drops to the lower level of a two-story mill structure (Figure 15).

Figure 13. The church in Lombada, Madeira, Portugal. The Levada do Moinho flows past the church (on the left) and then onto a bridge aqueduct along the west side of the praça

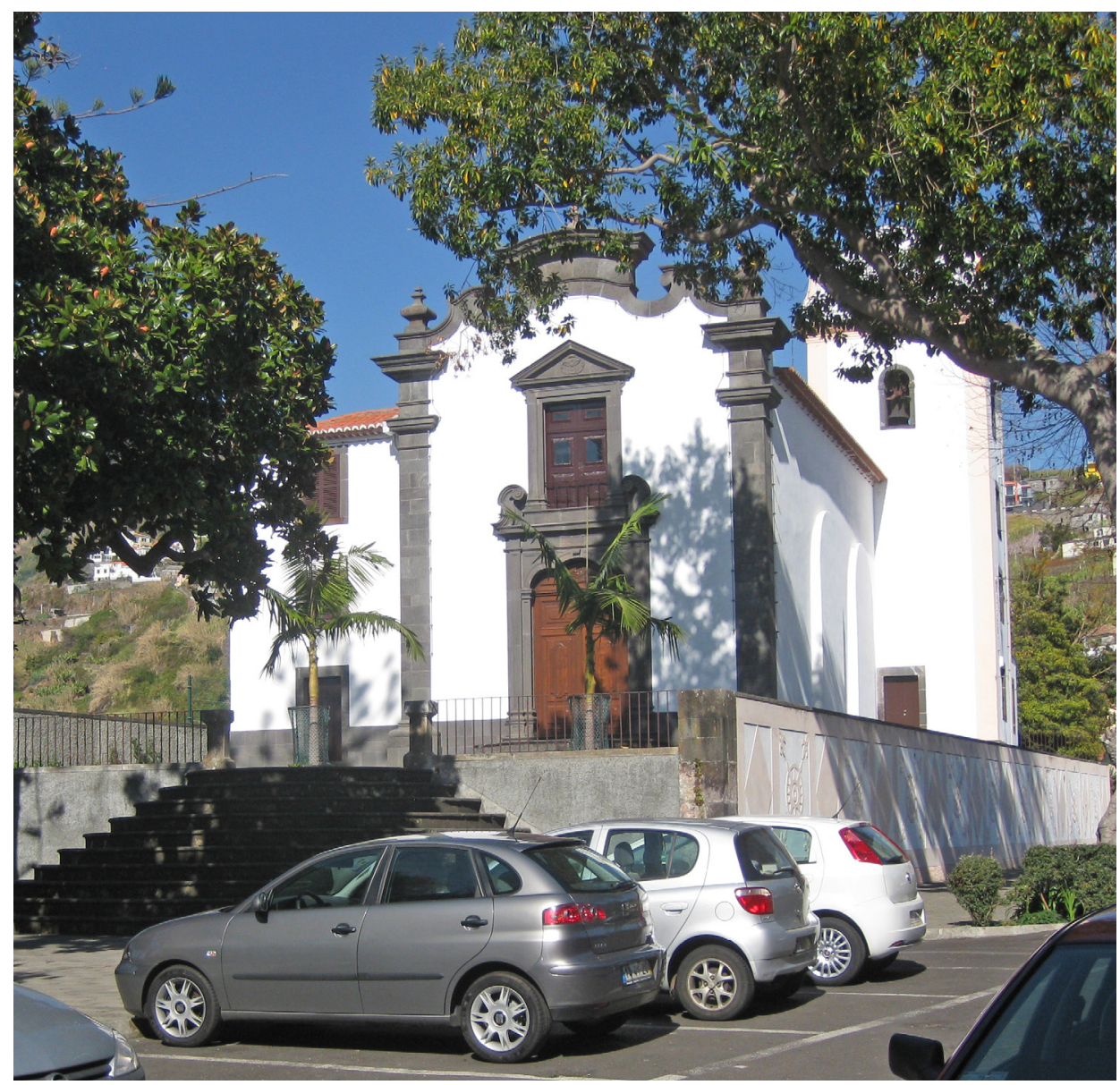


Figure 14. View along the top of the aqueduct that carries to the mill in Lombada. Compare this view with that in Figure 4.

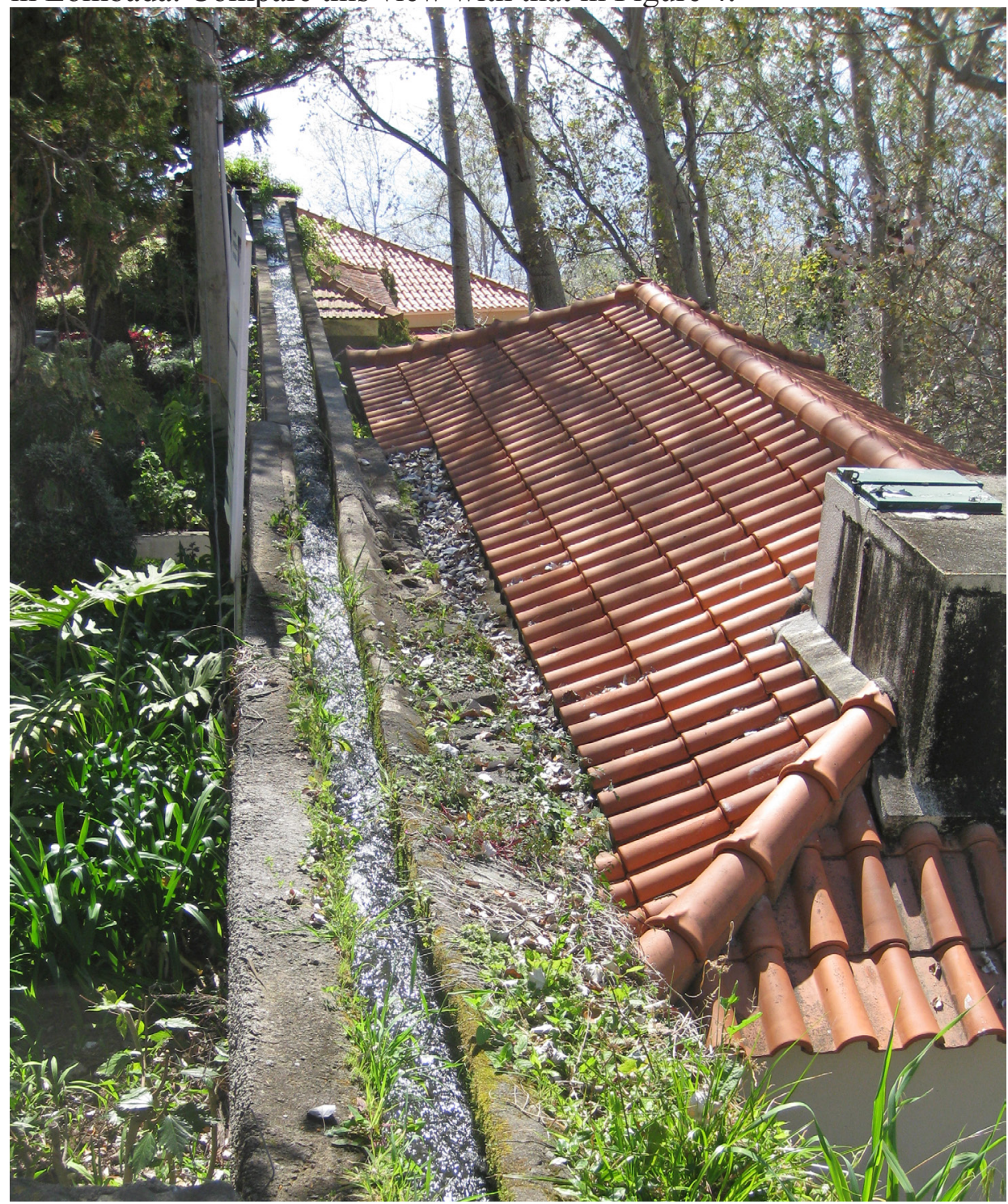

480 Revista Geográfica de América Central № 61E (3) Especial CLAG Este artículo está bajo una licencia

$\begin{array}{ll}\text { Revista Geográfica de América Central No } 61 \mathrm{E} \text { (3) Especial CLAG } & \begin{array}{l}\text { Este artículo está bajo una licencia } \\ \text { Atribución/Reconocimiento-NoComercial- }\end{array} \\ \text { e-ISSN 2215-2563 • Julio-diciembre 2018 • pp. 467-488 } & \text { Compartirlgual 4.0 Internacional }\end{array}$ Doi: http://dx.doi.org/10.15359/rgac.61-3.24 
Figure 15. The aqueduct and penstock (upper right), and the mill structure at Lombada. Note the steep, and natural, gradient of the road in the foreground.

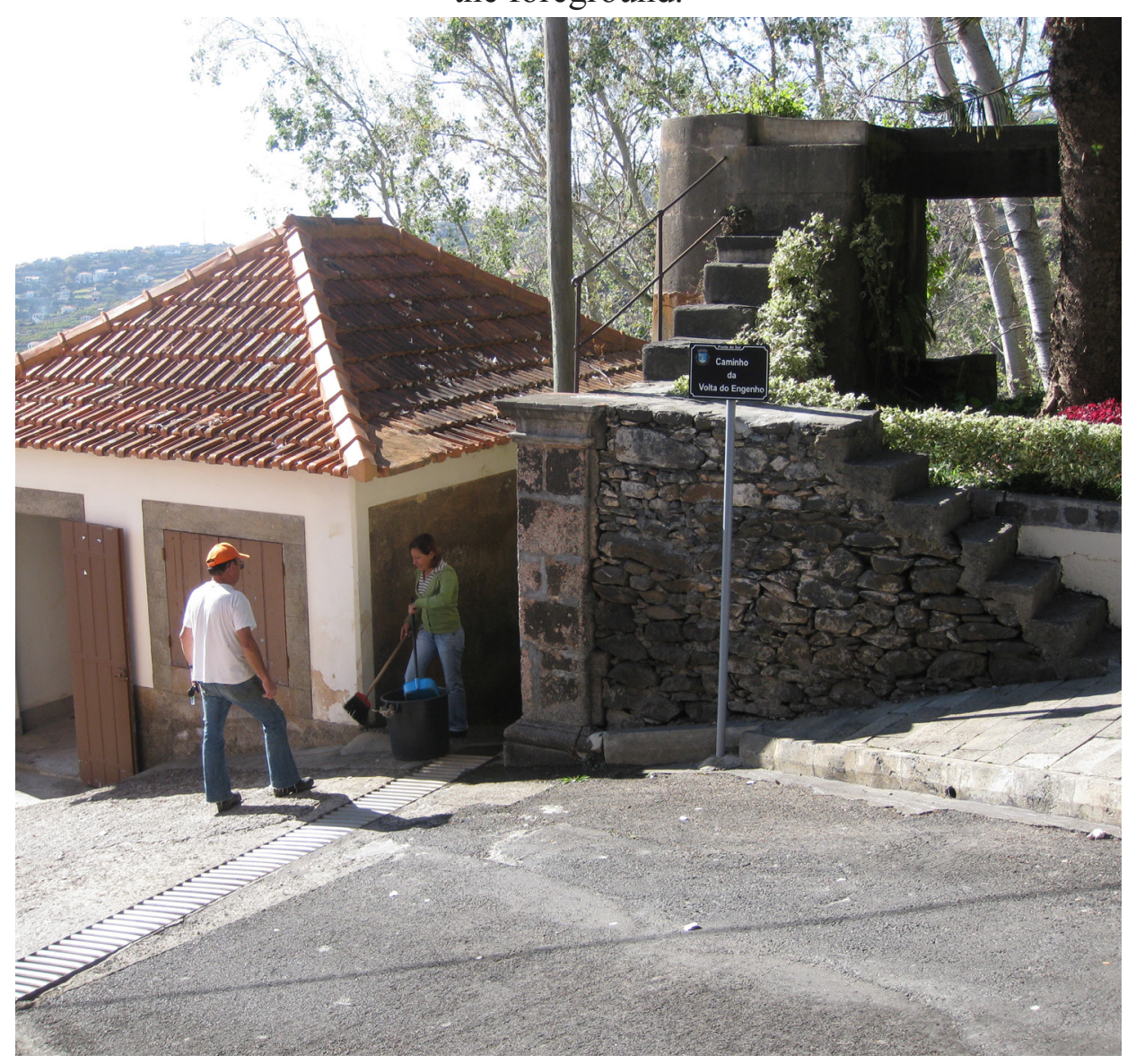

A gate at the bottom of the penstock can be opened to allow water to flow onto two horizontal turbines that can be operated simultaneously or separately (Figure 16). Water then exits the mill structure through a chase (Figure 17), and into a series of canals that irrigate crops in fields south of town. The vertical shafts extending upwards from the hubs of the turbines pass through the ceiling to the upper level of the mill structure. 
Figure 16. The two horizontal turbines turned by water falling through the penstock.

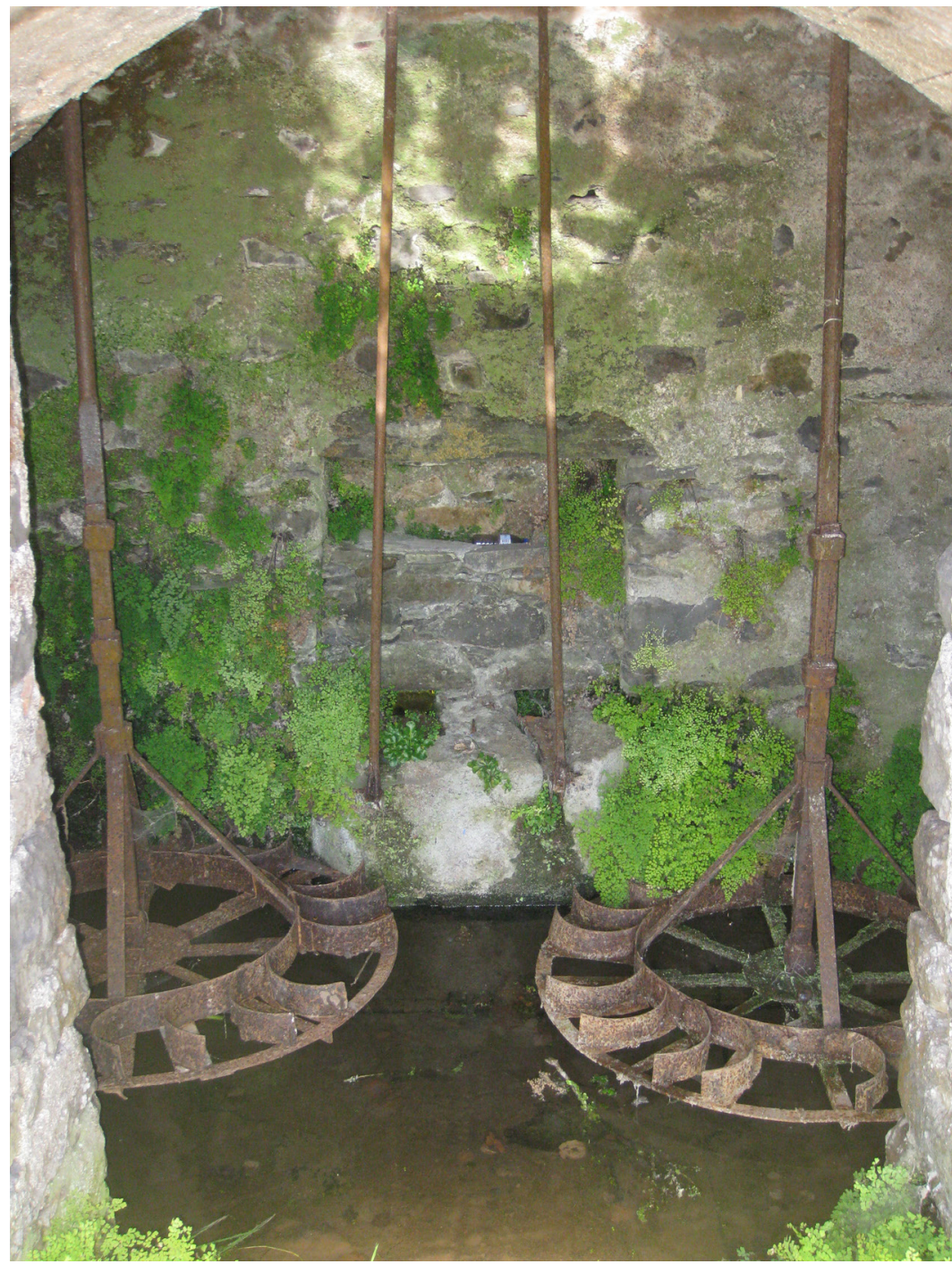


Figure 17. The downslope side of the mill structure at Lombada, Madeira. Evident are the chase below (compare with Figure 8) and the shuttered window on the second level where the millstones are located.

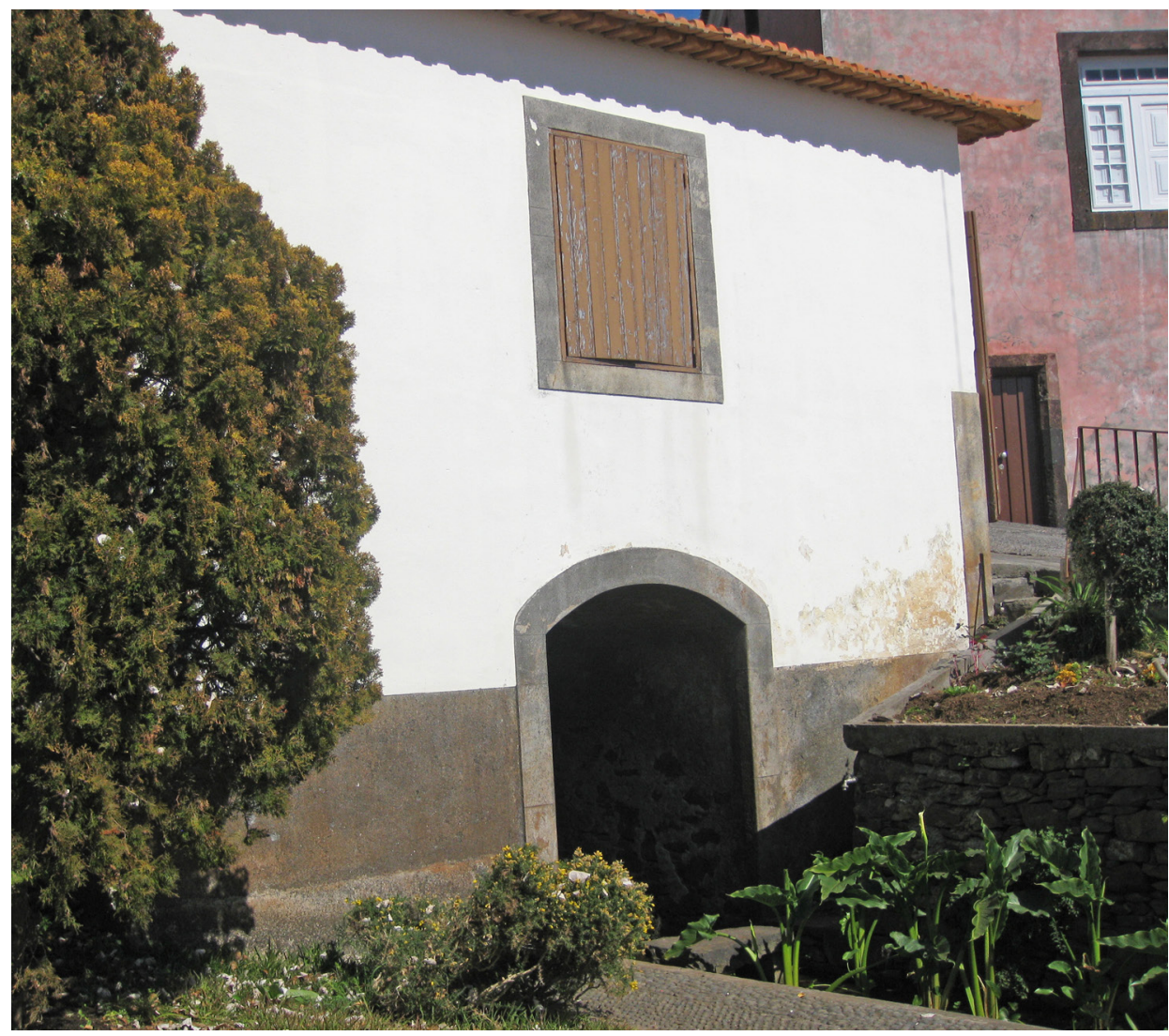

The actual milling apparatus is located on this second level (Figure 18). It involves two millstones that are fully enclosed, but accessible through hinged hatches. The hoppers in which grain to be milled is deposited are located above the enclosure. The entire apparatus is accessible from the street through the door evident in Figure 15. Each of the shafts from the water-turned turbine on the lower level passes through holes bored into the centers of a pair of stacked horizontal millstones. Each of the upper millstones is fastened to its respective shaft, and therefore rotates synchronously with the turbine below. Grain falling from the hopper through the hole in the upper stone is ground as the stone turns and emerges as meal or flour at the edges of the two stones. 
Figure 18. One of two pairs of millstones on the second or upper level of the mill structure at the town of Lombada. The upper stone is wrapped in a steel strap and is therefore distinct from the lower stone.

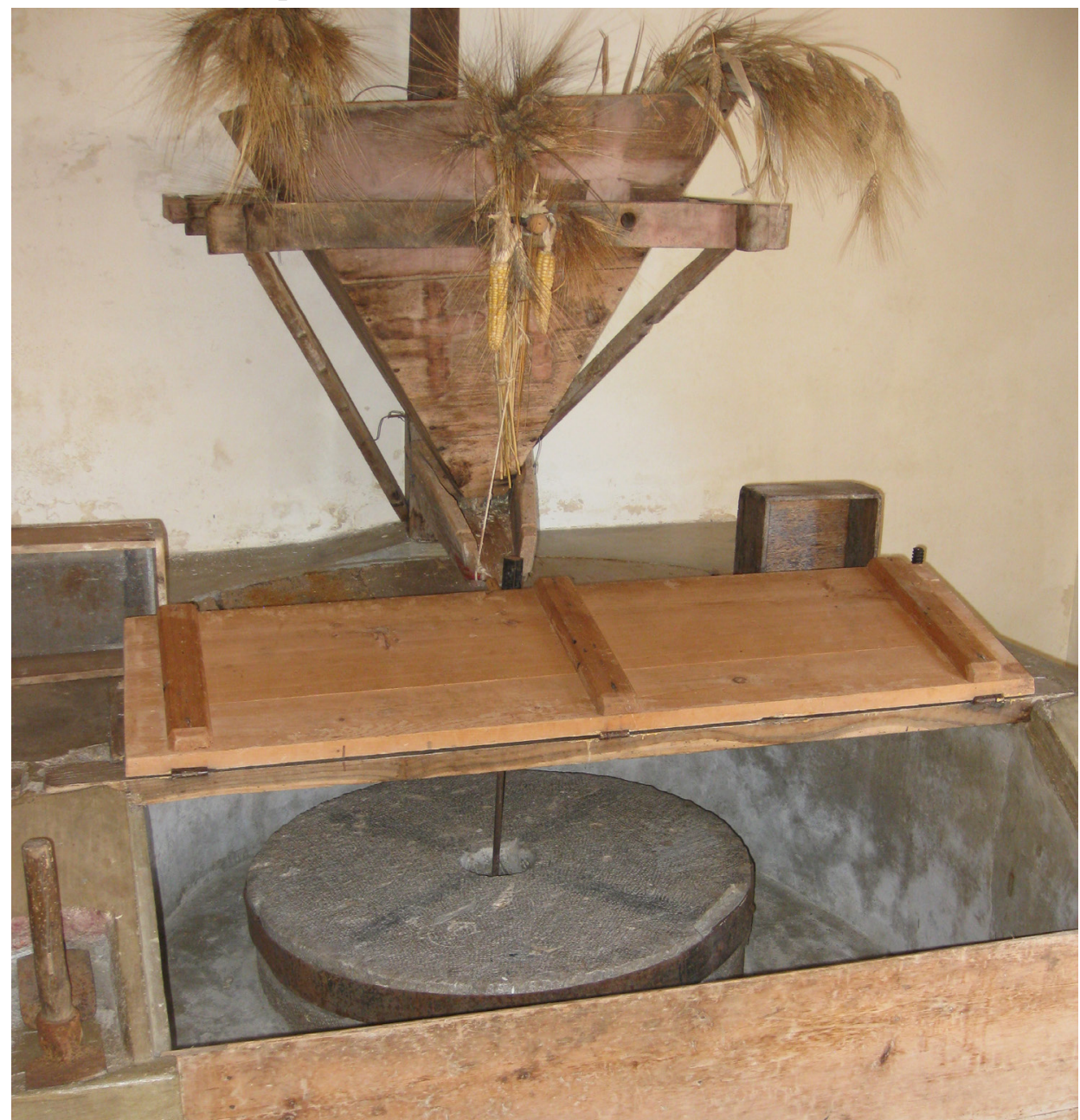

The mill stones on the second level are turned by the turbines on the first, and the turbines are turned by water falling through the penstock. Water flows into the penstock over the bridge aqueduct. Unlike its counterpart at Hacienda de Pacho, the bridge aqueduct at Lombada, Madeira involves neither Gothic arches nor even round ones, and indeed does not appear to be very old. This aqueduct is made of concrete and has square piers (Figure 
$19)$, and as such is clearly not a prototype or forerunner on which the $16^{\text {th }}$ century mill and aqueduct in Veracruz was modeled. Its predecessor, or one in the vicinity, could well have been.

Figure 19. The bridge aqueduct along the west side of the praça at Lombada, with its concrete channel and piers.

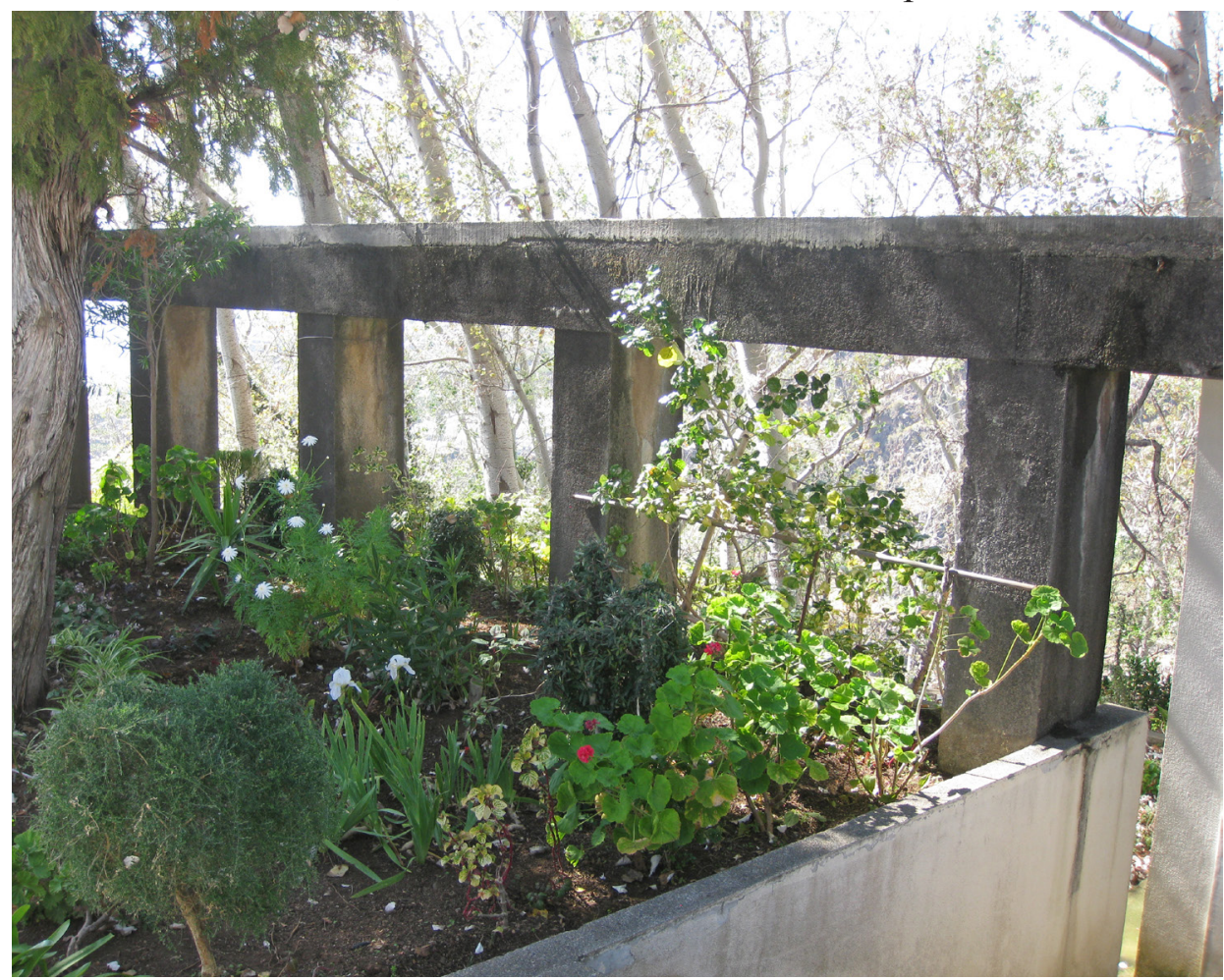

\section{The Age of the Madeiran Aqueduct}

Looks can be deceiving. The Levada do Moinho, including the mill and aqueduct bridge in Lombada, were rebuilt in 2011 at a cost of more than 2.6 million Euros. Funds were provided by the government of Portugal and the European Union. At first glance, this might seem to be a rather extravagant expenditure. When viewed as an investment, however, the picture changes considerably (Håkansson \& Widgren 2014). It could will yield huge rewards - perhaps as much as 70 billion Euros-over the next 550 years. 
Five-hundred fifty years is not simply a random number. The Levada do Moinho is at least that old. Settlement of Madeira began in the early 1400s (Greenfield 1977:539-541), and a water-powered gristmill was built there in AD 1452 (Greenfield 1977:544; Vieira 2004:52).

Whether or not this first mill on Madeira was the one in Lombada makes little difference. A mill existed on this site in the $15^{\text {th }}$ century (Underwood 2005:113). According to two local informants interviewed independently of each other, documents in the town archives verify that the mill was built in Lombada in AD 1461.

The European Union and the Portuguese government paid handsomely for renovating this levada because of its antiquity, and recognizing that if it functioned for 550 years, it might well function for another five plus centuries. In other words, its past speaks well for its future.

\section{Trans-Atlantic Technology Transfers and Transformations}

The aqueducts at both Lombada, Madeira, Portugal and Hacienda de Pacho, Veracruz, México have been modified substantially since their initial constructions. The mills with which they are a part were also renovated. Both of these mills could have served two very different purposes during the courses of their lives, the grinding of wheat at one time, and the grinding of sugar cane at another. The mills for these two crops differ considerably. Unlike gristmill that involve two horizontal stones turned by a water-powered horizontal turbine, sugar mills known as engenhos on Madeira in the $15^{\text {th }}$ century were of the horizontal double-roller type. They consisted of two parallel wooden cylinders that were in contact with each other, and were turned by a gearing mechanism powered by a vertical overshot water wheel. Cane was crushed by being inserted between the rollers (Gouviea 1985:269). This milling technology was transferred seamlessly from Madeira to the Canary Islands in the late $15^{\text {th }}$ century (Viera y Clavijo 1991:420), and then to the Caribbean island of Hispañola (Stevens-Acevedo 2013) and on to México (Crespo 1988 v. $1: 415)$ in the $16^{\text {th }}$ century.

Hacienda de Pacho was begun as a sugar mill in the late 1500s. However, its mill and associated aqueduct bridge might have been built initially for grinding grain. The penstock and the spandrel between it and the last arch are clearly additions. When these renovations are taken into

486 Revista Geográfica de América Central Nº 61E (3) Especial CLAG e-ISSN 2215-2563 • Julio-diciembre 2018 • pp. 467-488 Doi: http://dx.doi.org/10.15359/rgac.61-3.24 
consideration - that is visually removed - the aqueduct and flume look more like those typical of gristmills than sugar mills. The original mill structure would have been quite small.

The date of its renovation, and perhaps conversion to a sugar mill, is unknown. It is clear, however, that its production capacity was increased greatly, as the penstock was added and the mill structure enlarged. Both additions were doubtless made to accommodate a vertical overshot water wheel.

\section{Conclusion}

Documentary sources claim that the Hacienda de Pacho was established in the 1500 s by a Madeiran for the production of sugar. The Portuguese home of its founder is highly unusual for colonial México, as are the Gothic arches of the aqueduct associated with the mill. Field exploration on Madeira revealed 1) Gothic arches from the 1400s, 2) a long tradition of canal-building associated with agriculture, 3 ) the presence of mills with bridge aqueducts, 4) one canal-aqueduct-mill complex that dates to the middle of the $15^{\text {th }}$ century. Taken in concert, these material features agree with, and hence confirm, the documentary evidence. In the process, it raises a previously unasked question about about México. How much of its cultural landscape is a product of Portuguese rather than Spanish influences?

\section{References}

Cambrezy, L. \& Lascuráin, B. (1992). Crónicas de in territorio fraccionado de la hacienda al ejido (Centro de Veracruz). México: Ediciones Larousse. Chelmicki, J. C. C. de (2008). Memória sobre o Aqueducto Geral de Lisboa feita por ordem do Ministério das Obras Públicas em portaria de

15 de Fevereiro de 1856. Lisboa, Portugal: EPAL—Empresa Portuguesa das Águas Livres.

Crespo, H. (1988). Historia del Azúcar en México. 2 vol. México: Fonda de Cultura,Económica, e Azúcar, S.A.

Gouveia, D. F. de (1985). O Açucar de Madeira: A Manufactura Açucareira Madeirense (1420-1500), En: Atlantico [Funchal] 4, 260-272.

Greenfield, S. (1977). Madeira and the Beginnings of New World Sugar Cane Cultivation and Plantation Slavery: A Study in Institutional Building. En: Annals of the New York Academy of Sciences 292(4), 536-552. 
Håkansson, N. T. \& Widgren, M., eds. (2014). Landesque Capital: The Historical Ecology of Enduring Landscape Modifications. Walnut Creek, USA: Left Coast Press.

Hillman Chapoy, I. (2007). La Hacienda de Nuestra Señora de los Remedios también conocida como Hacienda de Pacho. Unpublished manuscript on file at Hacienda de Pacho.

Patel, R., \& Moore, J.W. (2017). A History of the World in Seven Cheap Things: A Guide to Capitalism, Nature, and the Future of the Planet. Los Angeles, USA: University of California Press.

Stevens-Acevedo, A. R. (2013). The Machines that Milled the Sugar-Canes: The Horizontal Double Roller Mills in the First Sugar Plantations of the Americas. Unpublished paper on File at the Dominican Studies Institute, City College of New York, USA.

Underwood, J. \& P. (2005). Landscapes of Madeira: A Countryside Guide. London, UK: Sunflower Books.

Valdes, O. (1961). El Padre Tembleque. México: Biblioteca Enciclopidica del Estada de México.

Viera y Clavijo, J. de (1991). Historia de Canarias, Las Palmas de Gran Canaria, España: Viceconsejería de Cultura y Deportes, Gobierno de Canarias.

Vieira, A. (2004). "Sugar Islands: The Sugar Economy of Madeira and the Canaries, 1450-1650," Tropical Babylons: Sugar and the Making of the Atlantic World, 1450-1680, Chapel Hill, USA: The University of North Carolina Press (pp. 42-84). 